Janine Lange*, Almuth Lietz, Jens Ambrasat, Jakob Tesch and Antje Wegner

\title{
The German Doctoral Candidates and Doctorate Holders Study ProFile
}

DOI 10.1515/jbnst-2015-1037

\section{Introduction and background}

This paper provides an overview of the longitudinal data set of the German Doctoral Candidates and Doctorate Holders Study ProFile which is available for analysis to researchers interested in the topics of doctoral training and careers of doctorate holders.

ProFile was developed against the background of a lack of information with regard to the conditions of doctoral training and careers of doctorate holders in Germany and the aim to also provide decision makers from academia, science and science policy with a sound empirical basis, encourage debates and support them with data.

In Germany the focus of the discussion lies mostly on the structural weaknesses of doctoral training and its organization (Hauss et al. 2012: 12f) for instance mechanisms of quality assurance (Guth 2006; Wissenschaftsrat 1996; Wissenschaftsrat 2002; Wissenschaftsrat 2011; Hochschulrektorenkonferenz 2012; Landeshochschulkonferenz Niedersachsen 2014) and the general supervision situation of doctoral candidates and their dependence on professors which is dominated in Germany by the master-apprentice model (Berning/ Falk 2005; Schmidt/Richter 2008). Another important topic is the funding and

\footnotetext{
*Corresponding author: Janine Lange, German Centre for Higher Education Research and Science Studies (DZHW), Research Area 2 "Research System and Science Dynamics", Schützenstraße 6a, 10117 Berlin, Germany, E-mail: lange@dzhw.eu

Almuth Lietz: E-mail: lietz@dzhw.eu, Jens Ambrasat: E-mail: ambrasat@dzhw.eu, Jakob Tesch: E-mail: tesch@dzhw.eu, Antje Wegner: E-mail: wegner@dzhw.eu, German Centre for Higher Education Research and Science Studies (DZHW), Research Area 2 "Research System and Science Dynamics”, Schützenstraße 6a, 10117 Berlin, Germany
} 
employment status during doctoral candidacy, their influence on time to degree and successful conferral of the $\mathrm{PhD}$ together with the subsequent occupational perspectives, placement and professional career (Enders/Bornmann 2001; Jaksztat/Schindler/Briedis 2010; Jaksztat/Preßler/Briedis 2012; Konsortium Bundesbericht Wissenschaftlicher Nachwuchs 2013). Furthermore, questions of adequate qualification are considered in terms of specific requirements of the academic and non-academic job market including competence acquisition and development (Schaeper/Briedis 2004; Vurgun 2016). Recently, the discussion has been shaped by the various emerging ways to the doctorate, for example as member of a structured doctoral program (SDP) and different traditional and non-traditional formats such as the research doctorate, the taught doctorate, $\mathrm{PhD}$ by published work, joint doctorate or new route doctorate (Green/Powell 2005; Bao/Kehm/Ma 2016) with ProFile facilitating analysis on those trending topics of international research, too.

ProFile was initiated by the Institute for Research Information and Quality Assurance (Institut für Forschungsinformation und Qualitätssicherung, iFQ) which is now part of the German Centre for Higher Education Research and Science Studies (Deutsches Zentrum für Hochschul- und Wissenschaftsforschung, DZHW). ${ }^{1}$

Since the beginning of the study in 2009 seven cohorts of doctoral candidates from selected German universities, graduate schools and scholarship providers have been surveyed on an annual basis until they completed or dropped out of their doctoral training and once after the conferral of their doctorate.

Designed as a service-oriented research project the goal pursued by the German Doctoral Candidates and Doctorate Holders Study ProFile is twofold: First, to provide a proper data base for doctoral education in Germany that can be used for a variety of research questions with regard to young scientists and second, to serve as a monitoring and evaluation tool for the participating institutions (see Table 1) based on annual reports which include benchmarks and results for institution specific questions.

In the following, ProFile's study design, the data set, the analytic potential and data access conditions will be described.

1 As of January 2016 the iFQ is part of the German Centre for Higher Education Research and Science Studies (DZHW). Here, it continues its work as Research Area 2 "Research System and Science Dynamics”. 
Table 1: Participating institutions and years with data delivery.

\begin{tabular}{ll}
\hline Type of institution & Participating institution \\
\hline Universities & Humboldt-Universität zu Berlin (2009-present), University of Kassel \\
& (2010, 2014-present), Heidelberg University (2009-present), Freie \\
& Universität Berlin (2009-present), Friedrich Schiller University in Jena \\
& (2009-present), Leibniz Universiät Hannover (2009-present), \\
& University of Osnabrück (2009-present), Otto von Guericke University \\
& of Magdeburg (2011-present), Goethe Graduate Academy at Goethe \\
& University Frankfurt (2012, 2014-present) \\
& Hartmut Hoffmann-Berling International Graduate School of Molecular \\
Graduate schools & and Cellular Biology (2009-present), International Graduate Centre for \\
& the Study of Culture (2009-2010), Graduate School for Advanced \\
& Manufacturing Engineering (2009-2010), Erlangen Graduate School in \\
& Advanced Optical Technologies (2009-2010), International Graduate \\
& School of Science and Engineering (2009-2010) \\
& German National Academic Foundation (Studienstiftung des Deutschen \\
Scholarship providers & Volkes, 2009-present), Heinrich Böll Foundation (2012-present), \\
& German Academic Exchange Service (Deutscher Akademischer \\
& Austauschdienst, DAAD, 2012-present)* \\
& German Research Foundation (Deutsche Forschungsgemeinschaft, \\
DFG): Research Training Groups and Collaborative Research Centres \\
(2009-2011)
\end{tabular}

Note: ${ }^{*}$ Scholarship holders in cooperating programs, individually funded ones intending to obtain a doctorate at a German University as well as scholarship holders funded in the program IPID (International Promovieren in Deutschland).

\section{Study Design}

\subsection{Sampling Design}

Registration procedures of doctoral candidates differ from university to university, since registration of doctoral candidates is not mandatory in Germany. ${ }^{2}$ The German Federal Statistical office published two studies in 2012 and 2016 that estimate the number of doctoral students (Wolters/Schmiedel 2012; Hähnel/ Schmiedel 2016). However, these estimations were not intended to function as

2 The current amendment of the university statistics act (Hochschulstatistikgesetz) strives to improve the nationwide registration of doctoral candidates and thus the data base for the assessment of the total number of doctoral candidates in Germany (Bundesministerium für Bildung und Forschung 2015). 
a selection frame for sampling and the underlying total population of doctoral candidates remains unknown. Thus, drawing a simple random sample is not possible (Fräßdorf/Fräßdorf 2016). Therefore, several universities, graduate schools and scholarship providers were contacted before the ProFile survey started in 2009 in order to get access to registers of doctoral candidates. The selection of participating institutions was primarily driven by the intention to reflect heterogeneity in contextual factors, respectively settings, in which a doctorate might be pursued and obtained and to yield sufficient sizes of subsamples for comparative analysis. The sample of universities was therefore intended to vary in terms of size, composition of disciplines and geographical location (Hauss et al. 2012: 49). In addition, the selection was also influenced by the fact that the respective institution needed to be willing to participate in the project and capable of assessing and transmitting the relevant data of their doctoral candidates (Hauss et al. 2012: 51). The participating institutions annually submit contact data of their doctoral candidates (encompassing email address, name, year of birth, gender and discipline). Even though the participating institutions were not sampled randomly, the selection of participating institutions in ProFile basically follows the logic of a cluster sampling where ProFile attempts full coverage at the level of the participating institutions - the primary sampling units - listed in Table 1.

\subsection{Survey design}

The study follows a panel design in the sense that it ideally surveys a doctoral candidate at the beginning of his or her doctoral candidacy, at least one time during the doctoral candidacy, at the conferral of the doctorate and once after the conferral of the PhD as illustrated in Figure 1. Every year, a new cohort of doctoral candidates is added to the survey.

The study foresees three surveys which are conducted by the DZHW: the Initial Survey, the Evaluation Survey and the Follow-Up Survey. Participants are invited through a personalized link to the online questionnaire via a bilingual email with English and German being the available survey languages.

The Initial Survey targets doctoral candidates who participate in ProFile for the first time. Even though the Initial Survey targets doctoral candidates at the beginning of their doctoral candidacy, due to the lacking necessity of prompt registration at universities, not all persons delivered are doctoral candidates. Instead, the data also contain persons who recently completed their doctorate or persons who stopped working on their doctorate (drop outs). About $5 \%$ of the respondents in the Initial Survey are doctorate holders and less than $1 \%$ report 


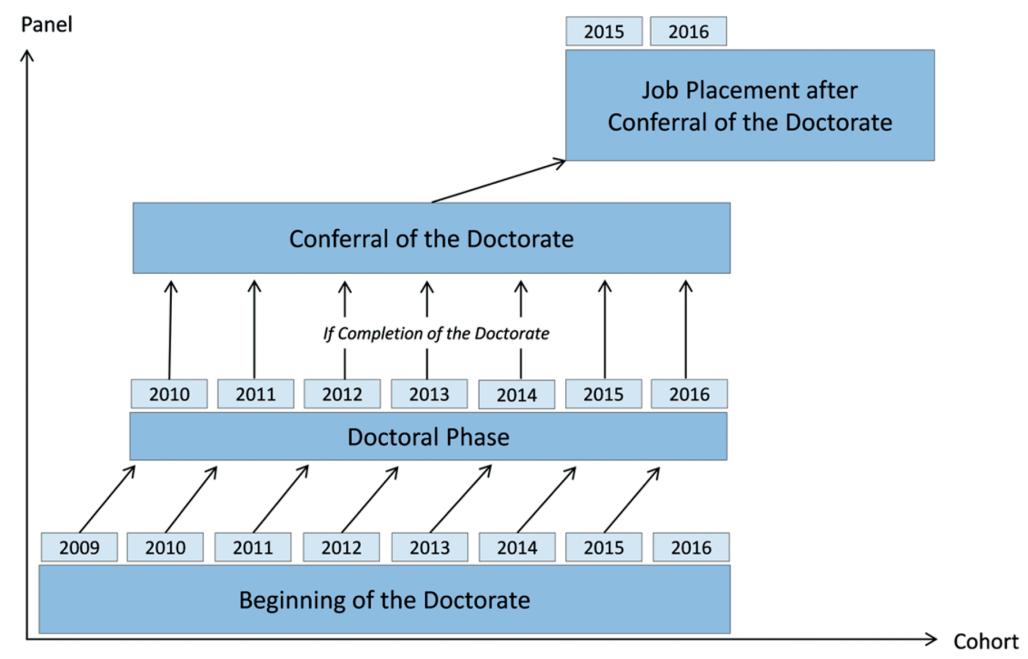

Figure 1: ProFile longitudinal design.

that they quit their PhD. The yearly Evaluation Survey focuses on persons who already participated in ProFile and stated that they are still doctoral candidates in the previous Evaluation or Initial Survey or those who completed their doctoral training in the meantime. The Follow-Up Survey targets doctorate holders who participated in ProFile at least once and completed their doctoral candidacy. ${ }^{3}$

\subsection{Questionnaire Design}

Since the status of the respondent is unknown prior to the invitation to the Initial and Evaluation Surveys, event triggered questionnaires have been implemented. Depending on the actual status of their doctoral project, which is assessed in the beginning of the Initial and Evaluation Survey, respondents are directed to varying questionnaires as depicted in Table 2. Thus, the status of the doctoral project serves as key variable for routing the participant to the correct questionnaire.

3 The Follow-Up Survey in 2015 questioned doctorate holders who had indicated the completion of their doctoral candidacy in any Initial or Evaluation Survey between 2009 and 2014, meaning that the award of the doctorate can date back several years. The Follow-Up Survey in 2016 additionally questioned doctorate holders who reported their conferral of the doctorate in the Evaluation Survey 2014 or Initial Survey 2015 but had not participated in the Follow-Up Survey 2015. 
Table 2: Overview of ProFile questionnaires implemented in the ProFile surveys.

\begin{tabular}{llll}
\hline & Initial survey & Evaluation survey & Follow-up survey \\
\hline $\begin{array}{l}\text { Doctoral } \\
\text { candidate }\end{array}$ & Initial Questionnaire for & Evaluation Questionnaire for & \\
Doctoral Candidates (PI) & Doctoral Candidates (PE) & \\
holder & Initial Questionnaire for & Evaluation Questionnaire for & Follow-Up \\
Drop out & Doctorate Holders (PtI) & Doctorate Holders (PtE) & Questionnaire (FQ) \\
\hline
\end{tabular}

The shaded cells in Table 2 display the questionnaires a ProFile participant ideally answers: The Initial Questionnaire for Doctoral Candidates (PI) focuses on information on the educational background, motives for a candidature, the supervision situation, the quality of courses offered, resources and questions about how doctoral candidates finance themselves during their doctoral candidacy. If the respondent's status of the doctoral project does not change during the next year he or she receives the Evaluation Questionnaire for Doctoral Candidates (PE) which aims at generating more information about the (possibly changing) conditions of their doctoral training. Conceptualized as a short questionnaire between the beginning and the conferral of the doctorate, it primarily considers changes in individual funding and supervision. If respondents indicate to have completed their degree, they receive the Evaluation Questionnaire for Doctorate Holders (PtE) which determines the successful conferral of the doctorate as well as job-related aims and perspectives. After the doctorate is finished, the Follow-Up Questionnaire $(F Q)$ focuses on job placement in and outside of academia as well as career trajectories after the conferral of the doctorate. It also aims at gaining more insight into job satisfaction, possible job strains and adequate occupation within or outside of academia. Table 3 gives a brief overview of the single topics covered in the different questionnaires.

\section{Data Set}

\subsection{Number of Respondents}

Altogether 15,649 doctoral candidates participated at least once in an Initial Survey from 2009 to 2015. Nearly half of them could be surveyed in an Evaluation Survey afterwards, from which 3,271 were questioned about their 
Table 3: Topics of the ProFile questionnaires.

\begin{tabular}{|c|c|c|}
\hline Topics & & Questionnaires \\
\hline \multicolumn{3}{|c|}{ Educational biography } \\
\hline & $\begin{array}{l}\text { Higher education entrance qualification } \\
\text { University degree } \\
\text { Vocational training qualification } \\
\text { Former doctoral project }\end{array}$ & $P I, P t l, A$ \\
\hline \multicolumn{3}{|c|}{ Doctoral project } \\
\hline & $\begin{array}{l}\text { Name of the university of doctoral project } \\
\text { Discipline } \\
\text { Thesis by publication/monograph } \\
\text { Time to degree } \\
\text { Candidate's motivation to start the PhD } \\
\text { Difficulties encountered during doctoral project }\end{array}$ & $P I, P t I$ (in retrospect), $A$ \\
\hline
\end{tabular}

Type and characteristics of structured doctoral

$P I, P t l$ (in retrospect), $A, P E$ program

Time use/time management

Scientific output (publications, conference

presentations)

Job offers during doctoral candidature

Supervision

Courses offered

Research stays in Germany and abroad

Financing and monthly household income

Vocational goals and aspirations

Intention to habilitate

Aspired occupation

Engagement at universities

Teaching activities

Reasons for interruptions and duration

Drop out

Reasons for drop out

A

Conferral of doctorate

Information on successful

Ptl, PtE

completion of the doctorate

Job placement

Professional status

$F Q$

Work field

Job description

Specific questions depending on professional status

Job search

Vocational prospects 
Table 3: (continued)

\begin{tabular}{ll}
\hline Topics & Questionnaires \\
\hline $\begin{array}{l}\text { Outcome } \\
\text { Honorary office }\end{array}$ & \\
Socio-demographics \& personal information & $P I, P t I$ \\
& Skills \& abilities \\
Self-efficacy & \\
Personality (Big Five) & \\
Individual risk attitude & \\
\hline Demography & $\begin{array}{l}\text { Fixed variables (e. g. gender, } \\
\text { year of birth) once. Children and } \\
\text { partnership in every survey. }\end{array}$ \\
\hline
\end{tabular}

Note: Institution specific questions are not listed in this table.

conferral of the doctorate. Up to now, 1,554 individuals were surveyed at all stages of their doctoral project (see Table 4). Since ProFile is still ongoing, this number of respondents will increase. As mentioned above, a few respondents are already doctorate holders in the Initial Survey and receive a specific questionnaire which surveys the beginning of the doctorate in retrospect and are questioned in the Follow-Up Survey, too.

Table 4: Number of respondents in surveys (2009-2015).

\begin{tabular}{|c|c|c|c|c|c|}
\hline \multicolumn{2}{|l|}{ Initial survey } & \multicolumn{2}{|c|}{ Evaluation survey } & \multicolumn{2}{|c|}{ Follow-up survey } \\
\hline $\begin{array}{l}\text { Doctoral } \\
\text { candidates (PI) }\end{array}$ & $\begin{array}{r}\text { Doctorate } \\
\text { holders (PtI) }\end{array}$ & $\begin{array}{r}\text { Doctoral } \\
\text { candidates (PE) }\end{array}$ & $\begin{array}{r}\text { Doctorate } \\
\text { holders (PtE) }\end{array}$ & $\begin{array}{l}\text { Doctorate } \\
\text { holders (FQ) }\end{array}$ & $\begin{array}{l}\text { Doctorate } \\
\text { holders (FQ) }\end{array}$ \\
\hline & & & & $\begin{array}{l}\text { from } \\
\text { Evaluation } \\
\text { survey }\end{array}$ & $\begin{array}{l}\text { from Initial } \\
\text { survey }\end{array}$ \\
\hline 15,649 & 1,352 & 7,082 & 3,271 & 1,554 & 574 \\
\hline
\end{tabular}

Source: ProFile data, own calculations 2016.

Note: Respondents are persons, who either completed the questionnaire or dropped out of it, but answered the status question at least.

\subsection{Sample composition}

The fact that besides universities also graduate schools and scholarship providers serve as primary sampling units doctoral candidates from these types of institutions are oversampled in the ProFile data. This was anticipated in order to allow 
in-depth analyses for these subgroups. Therefore, three samples need to be distinguished. Specific analyses on stipends can be run using the stipend sample which consists of doctoral candidates from graduate schools and scholarship providers exclusively. For analyses that are not solely focused on stipends the uni sample can be used. It consists of doctoral candidates at participating universities including scholarship holders from the participating graduate schools and scholarship providers, in case those doctoral candidates intend to graduate from one of the participating universities. The ones not intending to graduate from the participating universities are excluded from this sample. Both samples overlap in the parts of scholarship holders intending to graduate from participating universities. Taking into account the oversampling of stipends in the analyses, it is also possible to use the full sample. However, for descriptive statistics it is recommended to use the uni sample to avoid bias. Table 5 gives an overview of the number of respondents in the three samples for the Initial Surveys. The variation in the sample sizes results from changes in the composition of the participating institutions.

Table 5: Composition of respondents in uni, stipend, and full sample for the initial surveys.

\begin{tabular}{rrrr}
\hline & Uni sample & Stipend sample & Full sample \\
\hline 2009 & 1,081 & 1,551 & 2,463 \\
2010 & 1,134 & 657 & 1,697 \\
2011 & 1,137 & 1,028 & 2,050 \\
2012 & 1,055 & 1,174 & 2,095 \\
2013 & 1,442 & 725 & 2,085 \\
2014 & 2,071 & 870 & 2,836 \\
2015 & 1,527 & 999 & 2,423 \\
Total & 9,447 & 7,004 & 15,649 \\
\hline
\end{tabular}

Source: ProFile data, own calculations 2016.

\subsection{Data Quality}

Data quality is ensured by means of data monitoring and error correction at different stages. At the stage of data delivery the whole contact data delivered by the participating institutions is checked and corrected for duplicates. ${ }^{4}$ During

4 Since it is theoretically possible that one and the same doctoral candidate is reported by two different participating institutions, duplicates are identified by a routine based on names, email addresses, discipline and year of birth. 
field phase three reminders are sent and bounced email addresses are researched manually and invited again to increase response rates. ${ }^{5}$ In addition, respondents were provided with results from the survey in order to show its value and increase panel commitment. The response rates vary between $20 \%$ and $40 \%$ for Initial Surveys, $30 \%$ and $50 \%$ for Evaluation Surveys and over 50\% for Follow-Up Surveys. ${ }^{6}$ After data collection data editing includes anonymization, plausibility checking, coding of missing values and editing of central variables.

Furthermore, external validation was conducted on the level of the participating institutions and on the level of the whole sample. On the level of participating institutions the distributions of the data provided (gender, year of birth and discipline) and the data collected in the Initial Surveys are compared. On the level of the whole sample the uni sample of the Initial Survey 2015 can be compared with up-to-date official results of the Federal Statistical Office (Hähnel/Schmiedel 2016) which estimated the number of doctoral candidates at German universities by means of a two stage random sample where professors (as supervisors) and then doctoral candidates were asked to participate. The study concluded that there were about 196,200 doctoral students in Germany in winter semester 2014/2015. The comparison of the ProFile uni sample with the current results of the Federal Statistical Office is depicted in Table $6 .^{7}$

\section{Analytic Potential}

Currently, ProFile is the only survey in Germany that covers all disciplines, ${ }^{8}$ different types of doctorates (e.g. PhD by published work and taught

5 Response rate is the quotient of the respondents and the net subpopulation (gross subpopulation adjusted for persons without valid/undeliverable email adresses) multiplied by 100 .

6 The participating institutions differ in terms how data is transmitted to ProFile. The opt-in data procedure requires that doctoral candidates at the participating institutions give consent that their data is delivered to the DZHW. Partners with complete data submission transfer contact data of all their candidates to the DZHW without prior consent. The data collection procedure has consequences for the response rates: The opt-in procedure produces higher response rates.

7 Comparisons with results of an earlier estimation of the Federal Statistical Office of doctoral candidates in Germany in winter semester 2010/2011 by Wolters/Schmiedel (2012) with ProFile data also displayed only small differences concerning the distribution of candidates by gender and discipline (Hauss et al. 2012: 53).

8 Doctoral candidates from medical faculties are not included in the ProFile sample. This is in line with concerns that an unknown number of German doctoral degrees in Medicine may not 
Table 6: Doctoral candidates in official estimation and in ProFile by discipline and gender.

\begin{tabular}{|c|c|c|c|c|c|c|}
\hline & \multicolumn{3}{|c|}{$\begin{array}{r}\text { Doctoral candidates winter } \\
\text { semester } 2014 / 2015 \\
\text { estimation of Federal } \\
\text { Statistical Office in } \%\end{array}$} & \multicolumn{3}{|c|}{$\begin{array}{l}\text { Doctoral candidates ProFil } \\
\text { participants in Initial surve } \\
2015 \text { in } \%\end{array}$} \\
\hline & Women & Men & Total & Woman & Men & Total \\
\hline Linguistics and Cultural Studies & 61.0 & 39.0 & 18.0 & 59.9 & 40.1 & 25.0 \\
\hline Law, Economic and Social Sciences & 43.0 & 57.0 & 17.0 & 48.9 & 51.1 & 14.6 \\
\hline Sports & l & l & l & 60.0 & 40.0 & 0.3 \\
\hline Mathematics, Natural Sciences & 41.0 & 59.0 & 30.0 & 47.3 & 52.7 & 43.6 \\
\hline Medicine/Health Sciences & 58.0 & 42.0 & 10.0 & 64.7 & 35.3 & 1.1 \\
\hline Veterinary Medicine & l & / & / & 72.7 & 27.3 & 2.9 \\
\hline $\begin{array}{l}\text { Agricultural, Forestry and } \\
\text { Nutritional Sciences }\end{array}$ & 58.0 & 42.0 & 2.0 & 62.8 & 37.2 & 2.8 \\
\hline Engineering Sciences & 21.0 & 79.0 & 19.0 & 23.6 & 76.4 & 7.0 \\
\hline Fine Arts, Art History & 64.0 & 36.0 & 2.0 & 73.7 & 26.3 & 2.5 \\
\hline Other Discipline & l & l & l & 0.0 & 100.0 & 0.1 \\
\hline Total & 44.0 & 56.0 & 100.0 & 51.1 & 48.9 & 100.0 \\
\hline
\end{tabular}

Note: Values for Sports, Veterinary Medicine and Other Discipline were not reported in Hähnel and Schmiedel 2016. Source: Hähnel/Schmiedel 2016: 25ff, ProFile data, own calculations 2016.

doctorates) and at the same time spans different universities and funding organizations.

ProFile facilitates the analysis of changes and trends over time by comparing cross-sectional data of different cohorts and also longitudinal analysis of individual doctoral candidates and doctorate holders. ${ }^{9}$ Due to the longitudinal survey design of ProFile the candidates' progress can be ideally traced from the

be equivalent to an ISCED-8 degree and instead more closely resembles an ISCED-7 degree (Wissenschaftsrat 2002: 11). However, neighboring disciplines to Medicine are included in the ProFile sample (e. g. Human Biology, Health Sciences). The discipline contained in the data is based on an open answer in the survey. In case someone indicates to work on a medicine related topic this person receives the respective coding for Medicine.

9 Due to the very low number the ProFile data are not suitable for the analysis of drop outs. It is known that the number of drop outs in surveys is not representative. Estimates assume that $50 \%$ of doctoral candidates do not finish their doctoral training (Burkhardt 2008: 176ff). 
start of the doctoral candidacy to job placement after the conferral of the doctorate on an individual level. This long term monitoring makes it possible to detect changes over time whilst taking into account and controlling for individual factors as well as structural determinants that shape doctoral training and subsequent (research) careers.

To exploit the longitudinal data in particular, sequence and cluster analyses can be run, for example to reconstruct typical financing patterns, occupational transitions or mobility. In addition, event history analysis (e.g. to assess the time to degree) or multi-level analysis using information on discipline and university are possible. The ProFile data can also be linked with information from the European Tertiary Education Register (ETER) or the Leiden Ranking facilitating more in-depth analysis. ${ }^{10}$

Using the ProFile data, different topics concerning doctoral candidates and doctorate holders were explored during recent years. An extensive overview of results based on the diverse topics covered by the ProFile Study can be found in Hauss et al. (2012). Furthermore, the ProFile data were used to investigate the role and identity cultures of doctoral candidates in Germany (Kaulisch/Hauss 2012), the quality of doctoral candidacy (Hornbostel/Tesch 2014), the financing and employment situations of doctoral candidates (Fräßdorf/Kaulisch/ Hornbostel 2012), the intention to enter an academic career (Hauss/Kaulisch/ Tesch 2015), the specific situation of the doctoral candidacy in law (Tesch 2015) and the potentials of an empirical foundation of counselling services for future doctoral candidates (Fräßdorf/Hornbostel 2012). With a view to structured doctoral programs inherent expectations (Hauss/Zinnbauer 2011), the supervision situation (Hauss/Kaulisch 2012; Briedis et al. 2013) and the promotion of equal opportunities (Kaulisch 2011) were analyzed.

\section{Data access}

The ProFile data have been processed with funding from RISIS ${ }^{11}$ in order to make it available to the scientific community. As a European data and

10 The purpose of ETER is to build a register of Higher Education Institutions (HEIs) in Europe, providing data on the number of students, graduates, international doctorates, staff, fields of education, income and expenditure as well as descriptive information on their characteristics. Currently, aggregated information are available for 2254 HEIs (http://risis.eu/data/eter-dataset/). The Leiden Ranking offers insights into the performance and scientific collaboration of 800 major universities worldwide based on bibliometric information and indicators (http://www.leidenranking.com/).

11 Research Infrastructure for Research and Innovation Policy Studies (http://risis.eu/to) 
networking initiative, whose central objective is to combine and ensure access to different data sets, RISIS aims at building up a distributed infrastructure on data relevant for research, innovation dynamics and policies.

Interested researchers can apply for an on-site visit at DZHW in Berlin via the respective RISIS platform ${ }^{12}$ to get access to the ProFile data in the form of individualized Scientific Use Files (SUFs) that will be generated based on their specific interests and request. For this, they will have to undertake a two-step process: first, they have to register and sign the charter of good practice (accreditation) and then pass a review and selection process for their proposed project which is executed by the dataset producers and the RISIS project review board. Successful applicants from universities or research institutions outside of Germany may also apply for travel and accommodation funding through RISIS. The RISIS platform also contains relevant information on the ProFile data (e.g. data documentation, questionnaires). More information on the ProFile Study can also be found on the respective project homepage (http:// www.forschungsinfo.de/profile/start.html). Direct contact persons for further questions regarding the data set and conditions for guest researcher stays are Janine Lange (lange@dzhw.eu) and Jakob Tesch (tesch@dzhw.eu).

Funding: The development and implementation of the panel study between 2006 and 2015 was funded by basic institutional funding of the Institute for Research Information and Quality Assurance (iFQ) and received supplementary funding by the German Federal Ministry of Education and Research (BMBF) between 2007 and 2009. Funding for the preparation of the Scientific Use File was provided by RISIS - Research Infrastructure for Research and Innovation Policy Studies, a EU FP7 Research Program Project - grant agreement no: 313082.

\section{References}

Bao, Y., B. M. Kehm, Y. Ma (2016), From product to process. The reform of doctoral education in Europe and China, Studies in Higher Education (DOI: 10.1080/03075079.2016.1182481).

Berning, E., S. Falk (2005), Das Promotionswesen im Umbruch. In: Beiträge zur Hochschulforschung, Heft 1, Jahrgang 27, 48-72.

Briedis, K., S. Jaksztat, M. Kaulisch, J. Tesch, M. Zinnbauer (2013), A3.2.2 Betreuungssituation Promovierender in strukturierten und nicht strukturierten Promotionskontexten. In: Bundesbericht Wissenschaftlicher Nachwuchs 2013. Statistische Daten und

12 http://datasets.risis.eu/ 
Forschungsbefunde zu Promovierenden und Promovierten in Deutschland. Bielefeld: W.

Bertelsmann Verlag, 231-238.

Bundesministerium für Bildung und Forschung (2015), Gesetzentwurf der Bundesregierung.

Entwurf eines Gesetzes zur Änderung des Hochschulstatistikgesetzes.

Burkhardt, A. (2008), Wagnis Wissenschaft. Akademische Karrierewege und das Fördersystem

in Deutschland. Leipzig: Akademische Verlagsanstalt.

Enders, J., L. Bornmann (2001), Karriere mit Doktortitel? Ausbildung, Berufsverlauf und

Berufserfolg von Promovierten. Frankfurt a.M., New York: Campus.

Fräßdorf, A., M. Kaulisch, S. Hornbostel (2012), Armut und Ausbeutung? Die Finanzierungs- und

Beschäftigungssituation von Promovierenden. Forschung \& Lehre, 8/2012, 622-624.

Fräßdorf, A., S. Hornbostel (2012), Potentiale einer empirischen Fundierung von

Beratungsangeboten für (zukünftige) Promovierende. Zeitschrift für Beratung und Studium (ZBS), 2/2012, 34-37.

Fräßdorf, A., M. Fräßdorf (2016), Is there a Doctor on Board? Collecting Generalizable Data on Doctoral Candidates in Germany. Discussion Paper (DIW).

Green, H., S. Powell (2005), Doctoral Study in Contemporary Higher Education. New York: Open University Press.

Guth, J. (2006), The Bologna Process: The Impact of Higher Education Reform on the Structure and Organisation of Doctoral Programmes in Germany. Higher Education in Europe. 31(3), 327-338.

Hähnel, S., S. Schmiedel (2016), Promovierende in Deutschland. Wintersemester 2014/2015. Statistisches Bundesamt, Wiesbaden.

Hauss, K., M. Zinnbauer (2011), Hinter den Erwartungen. DUZ Magazin, Nr. 05/11, 20-21.

Hauss, K., M. Kaulisch, M. Zinnbauer, J. Tesch, A. Fräßdorf, S. Hinze, S. Hornbostel (2012),

Promovierende im Profil: Wege, Strukturen und Rahmenbedingungen von Promotionen in Deutschland. Ergebnisse aus dem ProFile-Promovierendenpanel. iFQ-Working Paper No.13. Berlin.

Hauss, K., M. Kaulisch (2012), Alte und neue Promotionswege im Vergleich. Die Betreuungssituation aus der Perspektive der Promovierenden in Deutschland. In: Huber, N., A. Schelling, S. Hornbostel (Hg.), Der Doktortitel zwischen Status und Qualifikation. iFQ-Working Paper No. 12. Berlin, 173-186.

Hauss, K., M. Kaulisch, J. Tesch (2015), Against all odds: Determinants of doctoral candidates' intention to enter academia in Germany. International Journal for Researcher Development, 122-143.

Hochschulrektorenkonferenz (2012), Zur Qualitätssicherung in Promotionsverfahren.

Empfehlung des Präsidiums der HRK an die promotionsberechtigten Hochschulen, Bonn.

Hornbostel, S., J. Tesch (2014), Die Forschungspromotion. Entwicklungstrends in Deutschland. Forschung \& Lehre, 8/14, 606-608.

Jaksztat, S., N. Preßler, K. Briedis (2012), Promotionen im Fokus. Promotions- und Arbeitsbedingungen Promovierender im Vergleich. Hannover: HIS Forum Hochschule.

Jaksztat, S., N. Schindler, K. Briedis (2010), Wissenschaftliche Karrieren. Beschäftigungsbedingungen, berufliche Orientierungen und Kompetenzen des wissenschaftlichen Nachwuchses. Hannover: HIS Forum Hochschule.

Kaulisch, M. (2011), Förderung der Gleichstellung durch Doktorandenprogramme. Ende einer Illusion? In: Löther, A. (Hg.), Arbeitsplatz Hochschule. Dokumentation der 22. Jahrestagung. 20.-22. September 2010. Trier. Bonn: Bundeskonferenz der Frauenbeauftragten und Gleichstellungsbeauftragten an Hochschulen e.V., 31-39. 
Kaulisch, M., K. Hauss (2012), Cultures of doctoral education in Germany: Beyond disciplines and disciplinary groupings? In: M. Vukasovic, P. Maassen, M. Nerland, R. Pinheiro, B. Stensaker, A. Vabø (eds.): Effects of Higher Education Reforms: Change Dynamics. Issues in Higher Education, 4. Rotterdam: Sense Publishers, 43-58.

Konsortium Bundesbericht Wissenschaftlicher Nachwuchs (2013), Bundesbericht Wissenschaftlicher Nachwuchs 2013. Statistische Daten und Forschungsbefunde zu Promovierenden und Promovierten in Deutschland. Bielefeld: W. Bertelsmann Verlag.

Landeshochschulkonferenz Niedersachsen (2014), Leitlinien zur Qualitätssicherung in Promotionsverfahren. Gemeinsame Position der Landeshochschulkonferenz Niedersachsens und des Niedersächsischen Ministeriums für Wissenschaft und Kultur.

Schaeper, H., K. Briedis (2004), Kompetenzen von Hochschulabsolventinnen und Hochschulabsolventen, berufliche Anforderungen und Folgerungen für die Hochschulreform. Kurz-information Hochschul-Informations-System, A6/2004, Hannover.

Schmidt, B., A. Richter (2008), Unterstützender Mentor oder abwesender Aufgabenverteiler? Eine qualitative Interviewstudie zum Führungshandeln von Professorinnen und Professoren aus der Sicht von Promovierenden. In: Beiträge zur Hochschulforschung, Heft 4, 30. Jahrgang, 34-58.

Tesch, J. (2015), Promovieren in der Rechtswissenschaft - Bedingungen und Strukturen im Vergleich zu anderen Disziplinen. In: Brockmann, J., A. Pilniok, H.-H. Trute, E. Westermann (Hg.): Promovieren in der Rechtswissenschaft, Baden-Baden: Nomos Verlag, 40-57.

Vurgun, S. (2016), Kompetenzen von Nachwuchswissenschaftlerinnen und Nachwuchswissenschaftlern. Entwicklung eines Kompetenzmodells, UniWiNDPublikationen, Band 6.

Wissenschaftsrat (1996), Empfehlungen zur Neustrukturierung der Doktorandenausbildung und -förderung. In: Wissenschaftsrat (Hg.): Empfehlungen und Stellungnahmen 1995. Köln, 7-76.

Wissenschaftsrat (2002), Empfehlungen zur Doktorandenausbildung. Drs. 5459/02, Saarbrücken.

Wissenschaftsrat (2011), Anforderungen an die Qualitätssicherung der Promotion. Positionspapier, Köln.

Wolters, M., S. Schmiedel (2012), Promovierende in Deutschland. 2010. Statistisches Bundesamt, Wiesbaden. 